\title{
Information Communication Technology Adoption and Efficiency of Student Services
}

\author{
IDENMAE M. PALOMO \\ macabecha30@yahoo.com \\ DENNIS G. CANAMAN \\ denjaze@yahoo.com \\ Liceo de Cagayan University
}

\begin{abstract}
Date Submitted: January 20, 2007
Final Revision Accepted: May 8, 2007
\end{abstract}

\begin{abstract}
The study investigated the influence of information and communication technology on the efficiency of student services of Liceo de Cagayan University. The descriptive research used 20 service providers and 100 clients as respondents. As rated by the clients, the university obtained a satisfactory rating for its ICT practices in terms of system restructuring, system selection, ICT staff's skills and capabilities. For ICT applications, as rated by the service providers, the university got a satisfactory rating on functionality, availability, maintainability, and utilization. As to the efficiency of the different departments' student services, as rated by the service providers, the university got a very satisfactory rating for the Registrar's Office, Cashier's Office, Library, and Internet Services. The predictors of the efficiency of student services were ICT implementation in terms of timely provision of information to other providers with student support roles and ICT practices in terms of ICT as a tool for competitive advantage and survival, as a tool for testing and altering school's administrators' know-how to get things done in the existing system, and as a tool for day-to-day operation.
\end{abstract}

Key words - ICT practices and application, effeciency of student services 


\section{INTRODUCTION}

Information Communication Technology (ICT) facilitates communication and the processing and transmission of information by electronic means. This broad definition encompasses the full range of ICTs from radio and television to telephones (fixed and mobile), computers, and the Internet (Cummings 2005). The revolutionary potential of Information Communication Technologies lies in their capacity to instantaneously connect vast networks of individuals and organizations across great geographic distances at very little cost. As such, ICTs have been key enablers of development, facilitating flows of information, capital, ideas, people, and products (Cook \& Finlayson 1999). An explicit focus on using ICTs in pursuit of development goals allows countries to achieve a wide diffusion of benefits from ICTs and contributes to both broad-based economic growth and specific development goals (Giarola 2004).

Moreover, a holistic approach that sees ICTs as key development enablers recognizes that the potential of ICTs is linked to a complex mixture of international, national, and local conditions. A number of interrelated factors should be addressed to maximize the benefits of ICTs for development. These include deploying ICT infrastructure, building human capacity, establishing a transparent and inclusive policy process, creating incentives for enterprise, and developing appropriate content (Pearlson \& Saunders 2005).

For all these to be realized, there is a need to understand the critical relationships between various strategic interventions in the context of local conditions and to secure the participation and commitment of all key stakeholders; local communities, non-governmental organizations (NGOs), the government, and the private sector.

The advantages offered by ICTs are the removal of barriers of space and time in learning, opening up of different languages and cultures of the world, and creation of a more equitable learning environment. ICTs provide a means for overcoming historically intractable problems of isolation, lack of access to information and knowledge, and crucial impediments to educational and socioeconomic development (Lucas 1997). ICTs have reshaped the educational landscape by transforming the content and modes of delivery/acquisition of learning as well as how the educational institutions operate (Kallick \& Wilcon 2001). The ICTs in the form of hardware and software, network devices, communication and information system development (telephones, fax machines for transmittal of documents on 
school to school basis), Internet, Local Area Network (LAN) to provide open communication among school employees, and software applications (Microsoft Word, Microsoft Excel, and MS-DOS programs) are the applications mainly used by the Liceo de Cagayan University.

\section{FRAMEWORK}

The independent variables included the existing practices of ICT, system restructure that examines and implements redesigned process of an organization, system selection or the procedure adopted in selected applications by ICT for the different vendors, and ICT staff's skills and capabilities that cover experience, training, and educational background. Other independent variables were the performance level of ICT implementation, which refers to how it is implemented; functionality, which refers to the number of ICT supported functions in the system; availability, which is the property that makes data accessible and useable upon demand by the user; maintainability, which is a process that characterizes the design and installation, expressed that an item will be restored in a specific condition in a given period of time; and utilization, which refers to the assessment of the extent that functions are provided to improve process performance, ease of use, and level of knowledge among users. These independent variables were hypothesized to impact directly the efficiency of student services.

The ICT performance level was assessed in terms of its functionality, availability, maintainability, and utilization. Determining ICT performance level also included the evaluation of hardware, software, and network components and services coordination with the service provider (Giarola 2004). Basically, the key components of successful ICT implementation are system restructure, system selection, and ICT staff's skills and capabilities (Lango 2005).

\section{OBJECTIVES OF THE STUDY}

The study aimed at assessing the university's extent of ICT practice and applications as predictors of the efficiency of student services of the Liceo de Cagayan University. Specifically, the study sought to answer the following objectives: (1) to describe the profile of the respondents; (2) to describe the university's extent of the ICT practices for student services; (3) to assess the university's level of the ICT applications; (4) to compare the ratings of service providers and clients on the ICT adoption; (5) to measure the level of efficiency of the student services of the 
departments; and (6) to find the predictors of efficiency of student services.

\section{METHODOLOGY}

The descriptive research method was employed in the conduct of the study. Zulueta and Costales (2003) stressed that the descriptive method seeks to provide information about one or more variables and is used to answer the question "what exists?" The study used the correlation technique because it traced the relationship between the independent and dependent variables. The study was conducted at the Liceo de Cagayan University, specifically at the Registrar's Office, Cashier's Office, Library, and the Internet Services that use ICT in their daily operations. The respondents of the study were the 20 employees (service providers) and the students (clients) of the university. The employees use the ICT in performing their assigned tasks. The researchers used the list of office staff to determine the service provider respondents. The quota sampling was employed for student respondents. One hundred students were sampled proportionately by course.

Table 1. Distribution of respondents

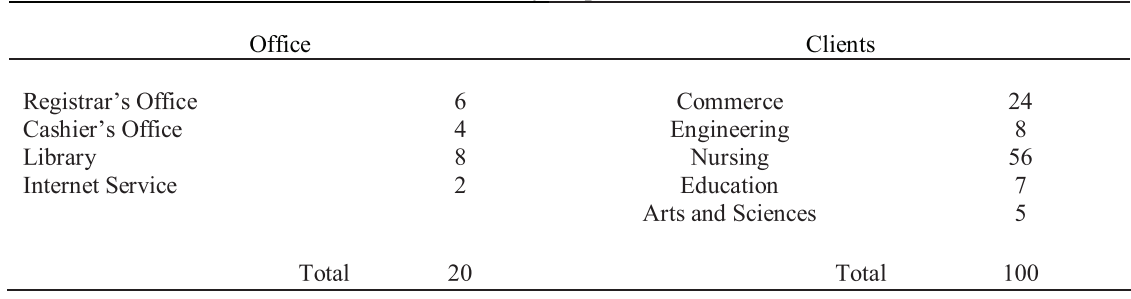

The main instrument used in the collection of data was the standardized questionnaire on the implementation of information and communications technology. Part I of the questionnaire, which had two subparts, dealt with the respondent's profile. Subpart 1 pertained to the employees/service providers' profile in terms of educational attainment, field of specialization, number of inservice trainings/programs attended, and number of years in service, in-service trainings/programs attended, and services offered. Subpart 2 pertained to the clients' profile in terms of age, sex, course, and major. Part II dealt with the practices in ICT in terms of system restructure, system selection, ICT staff skills/capabilities, and editing practices of ICT; ICT applications in terms of functionality, availability, maintainability, utilization, performance level; and the efficiency of student services in the Registrar's Office, Cashier's Office, Library, and Internet Services. The instrument was adapted from "Survival of the Smartest and Do It Smart" as cited by Tiin, (2000), "Funding Guidance for Schools and Local Authorities" 
by Bas (2003), and the Internet articles. The researchers secured from the service offices permission to conduct the study. The heads of the service offices were then requested to assist the researchers in the administration of the questionnaires to their staff. The respondents were given half an hour to answer the questionnaires, which were then retrieved immediately.

\section{RESULTS AND DISCUSSION}

Profile of the Respondents

Table 2 presents the profile of the Liceo service providers. As shown, the majority of the respondents were college graduates (15 or 75.5\%), followed by those with units in the masteral study ( 3 or 15.0\%) and those with units in the doctoral study (2 or $10.0 \%$ ). In terms of field of specialization, more than half of the providers were computer trained when assigned to the office (13 or $65.0 \%$ ). Only a very few earned a computer-related course such as information technology (4 or $20.0 \%$ ), short-term computer course (2 or 10.0\%), and computer engineering (1 or $2.5 \%$ ). As to the service providers' number of in-service trainings/programs attended, majority of the respondents attended for 6 to 10 times (7 or 35.0\%), followed by those who attended for 10 times or more and for 1 to 5 times ( 3 or $15.0 \%$ ). However, there were a few ( 5 or $25 \%$ ) who had not attended any in-service trainings at all. On the number of years in service, majority of the respondents have served for 1 to 5 years (7 or $35.0 \%$ ), followed by those who have served for 6 to 10 years ( 6 or $30.0 \%$ ), 11 to 15 years ( 4 or $20.0 \%$ ), and above 15 years ( 3 or $15.0 \%$ ). The findings suggest the staff had limited ICT capabilities who are assigned in offices that utilize ICT in their services.

Table 2. Profile of Liceo service providers

\begin{tabular}{|c|c|c|c|}
\hline Respondents Profile & Categories & Frequency & Percent \\
\hline & College Graduate & 15 & 75.5 \\
\hline Educational & College Graduate with Master Units & 3 & 15.0 \\
\hline \multirow[t]{4}{*}{ Attainment } & Masteral Degree with doctorate units & 2 & 10.0 \\
\hline & Total & 20 & 100.00 \\
\hline & Computer Engineering (Comp. Eng'g.) & 1 & 2.5 \\
\hline & Short-term Computer Courses & 2 & 10.0 \\
\hline \multirow{4}{*}{$\begin{array}{c}\text { Field of } \\
\text { Specialization }\end{array}$} & Information Technology & 4 & 20.0 \\
\hline & $\begin{array}{l}\text { Computer Trained when assigned to } \\
\text { office }\end{array}$ & 13 & 65.0 \\
\hline & Total & 20 & 100.00 \\
\hline & $1-5$ & 3 & 15.0 \\
\hline Number of in-service & $6-10$ & 7 & 35.0 \\
\hline \multirow[t]{5}{*}{ trainings/programs attended } & None & 5 & 25.0 \\
\hline & Above 10 & 5 & 25.0 \\
\hline & Total & 20 & 100.00 \\
\hline & 1 to 5 years & 7 & 35.0 \\
\hline & 6 to 10 years & 6 & 30.0 \\
\hline \multirow[t]{4}{*}{ Number of Years in service } & 11 to 15 years & 4 & 20.0 \\
\hline & Above 15 years & 3 & 15.0 \\
\hline & Total & 20 & 100.00 \\
\hline & Overall Total & 60 & 100.00 \\
\hline
\end{tabular}


Table 3 shows the profile of the Liceo clients in terms of age. Majority of the respondents aged 19 to 20 years old ( 39 or $39.0 \%$ ), followed by those who aged 21 to 22 years old ( 30 or $30.0 \%$ ), 23 to 24 years old (15 or $15.0 \%$ ), 27 to 28 years old (6 or $6.0 \%$ ), 17 to 18 years old ( 5 or $5.0 \%$ ), 25 to 26 years old ( 4 or $4.0 \%$ ), and 29 to 33 years old (1 or $1.0 \%)$. In terms of gender, the female clients composed the majority (67 or $67.0 \%$ ), while the male clients accounted for only 33 percent. As regards the clients' course, majority were Nursing students (56 or $56.0 \%$ ). Only $24 \%$ (24) were Commerce students; 8\% (8), Engineering students; 7\%, Education students; and $5 \%$ (5), Arts and Sciences students. The findings indicate the clients are in the age bracket which is ICT oriented and trained.

Table 3. Profile of Liceo clients

\begin{tabular}{|c|c|c|c|}
\hline Respondents' Profile & Categories & Frequency & Percent \\
\hline \multirow{8}{*}{ Age } & $17-18$ & 5 & 5.0 \\
\hline & $19-20$ & 39 & 39.0 \\
\hline & $21-22$ & 30 & 30.0 \\
\hline & $23-24$ & 15 & 15.0 \\
\hline & $25-26$ & 4 & 4.0 \\
\hline & $27-28$ & 6 & 6.0 \\
\hline & $29-33$ & 1 & 1.0 \\
\hline & & 100 & 100.00 \\
\hline \multirow{3}{*}{ Gender } & Male & 33 & 33.0 \\
\hline & Female & 67 & 67.0 \\
\hline & & 100 & 100.00 \\
\hline \multirow{4}{*}{ Course } & Arts and Sciences & 5 & 5.0 \\
\hline & Commerce & 24 & 24.0 \\
\hline & Education & 7 & 7.0 \\
\hline & Engineering & 8 & 8.0 \\
\hline \multirow{14}{*}{ Major } & Nursing & 56 & 56.0 \\
\hline & & 100.00 & 100.00 \\
\hline & Psychology & 5 & 5.0 \\
\hline & Management Acctg. & 10 & 10.0 \\
\hline & Accountancy & 2 & 2.0 \\
\hline & Finance & 6 & 6.0 \\
\hline & Marketing & 6 & 6.0 \\
\hline & Elementary Education & 7 & 7.0 \\
\hline & Electronics and Communication Engineering & 2 & 2.0 \\
\hline & Electrical Engineering & 2 & 2.0 \\
\hline & Industrial Engineering & 2 & 2.0 \\
\hline & Civil Engineering & 2 & 2.0 \\
\hline & Nursing & 56 & 56.0 \\
\hline & & 100.00 & 100.00 \\
\hline
\end{tabular}

Among those in the library, the in-service trainings/programs attended were on Follet, Excel, Microsoft Word, library method, computer literacy, book indexing, on-line database, and SRC/AC. For those in the Internet Services, the in-service trainings/programs attended were on Flash guard, web page and adobe, web development, and CISCO. Those in the Cashier's Office attended trainings/programs on computer literacy, sales advertising, and other topics conducted by the Human Resource Department. Those in the Registrar's Office 
attended trainings/programs on computer literacy and other topics conducted by the Human Resource Department. The library has the following services: use of computer, locating and finding books, inventory, indexing books, use of audiovisual materials, photocopying, publication of newsletters, system updating, online database research, pathfinders (pdf), CD-Rom, book and periodical borrowing, computer-assisted research, searching, reserving books, and library instruction. The Internet services include the Internet, network installation, web development, software and hardware installation, access, downloading, Internet mail, dial-up, computer maintenance, and networking setup. The services of the Cashier's Office are assessment, refunding, fees payment, and issuance of certificates, transcript of records, and diploma. The Registrar's Office offers the following services: processing of grades and NG's and processing and release of the TOR, diploma, and certificate of honorable dismissal.

Table 4. Liceo service providers' in-charge trainings/programs attended and services offered

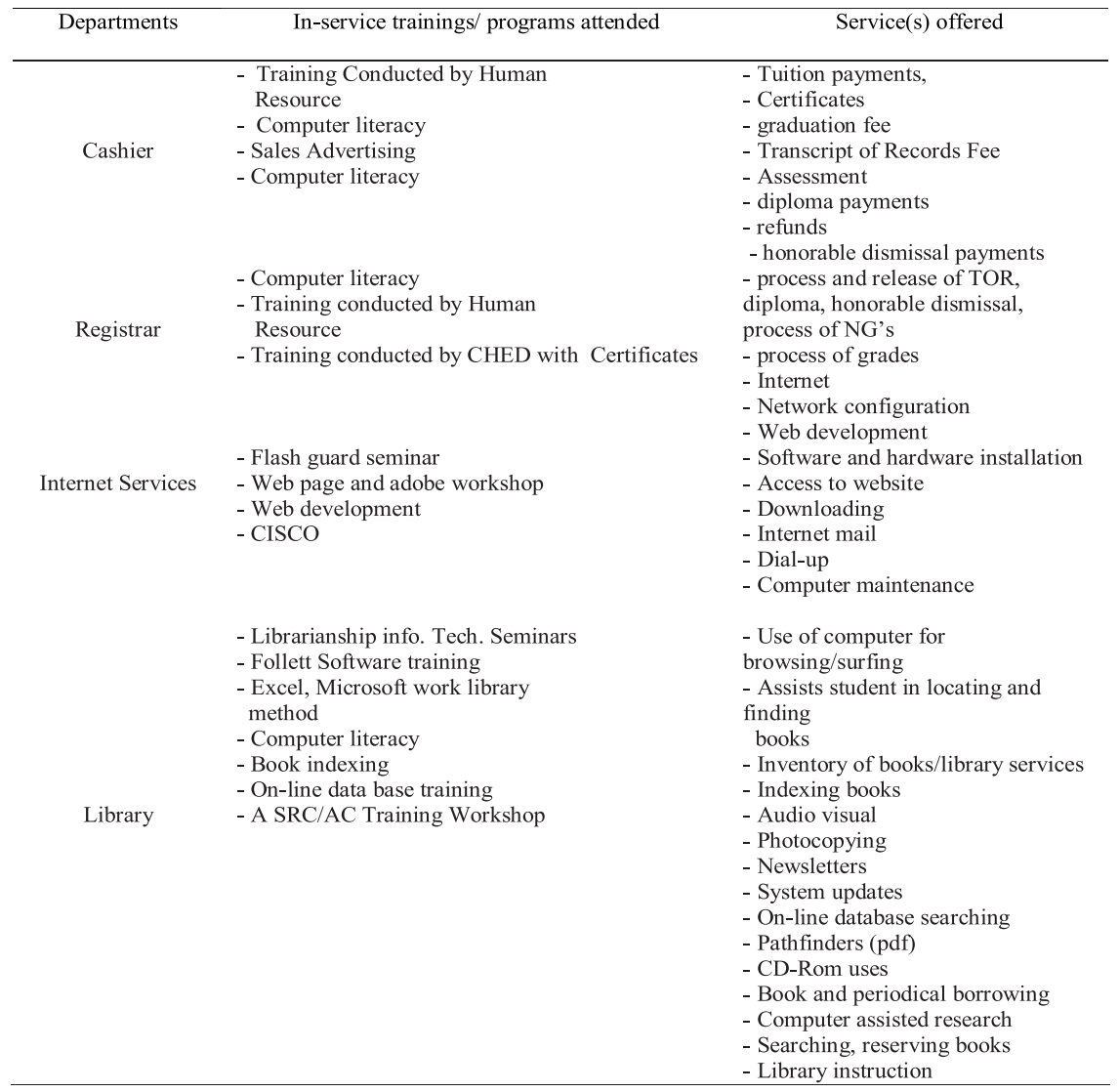


The service providers offer such services to better serve the clients who are the direct beneficiaries of the ICT implementation.

\section{Extent of the Existing ICT Practices}

Table 5 shows the Liceo service providers' ratings on the system restructuring. As reflected by the overall mean of 3.21, system restructuring was practiced satisfactorily. The indicators rated very satisfactory were the updating of new software (3.25) and giving importance on the efficiency of the system (3.25). Other indicators rated satisfactory included minimizing complexity (3.22), building a chain of networks (3.20), and involving users intensively in the system restructuring (3.15). The findings imply that the service providers are satisfied with the use of the system.

Table 5. Liceo service providers' ratings on system restructuring

\begin{tabular}{|c|c|c|}
\hline System Restructure & Weighted Mean & Verbal Description \\
\hline Updates new software in the market & 3.25 & Very Satisfactory \\
\hline Involves the users intensively in the system restruct ure & 3.15 & Satisfactory \\
\hline Gives importance on the efficiency of the system. & 3.25 & Very Satisfactory \\
\hline Minimizes complexity & 3.22 & Satisfactory \\
\hline Builds a chain of networks & 3.20 & Satisfactory \\
\hline ( & 3.21 & Satisfactory \\
\hline
\end{tabular}

Table 6 discloses the Liceo clients' ratings on system restructuring. The overall rating of 2.62 indicates that the system was satisfactory. All the indicators were rated satisfactory as well. The data imply that the clients are not intensively involved in the system restructuring of the ICT. They could hardly make suggestions to improve the system.

Table 6. Liceo clients' ratings on system restructuring

\begin{tabular}{|c|c|c|}
\hline System Restructure & Weighted Mean & Verbal Description \\
\hline Uses new software available in the market. & 2.71 & Satisfactory \\
\hline Involves the users intensively in the system restructure & 2.60 & Satisfactory \\
\hline Minimizes complexity & 2.56 & Satisfactory \\
\hline Mean & 2.62 & Satisfactory \\
\hline
\end{tabular}

Table 7 reveals the Liceo service providers' ratings on system selection. The indicators rated very satisfactory were ICT system's adjustment to the existing system of the university (3.30), the use of standard software available in the market (3.32), and ICT system's flexibility for any additional functions for needed services (3.25). Only one indicator was rated satisfactory-that is, the involvement of the users in the system selection (3.16). Overall, system selection was rated very satisfactory (3.25) by LDCU service providers as reflected by the overall rating of 3.25. The service providers are very satisfied with the system selection of ICT because it enables them to adjust to the existing system of the university, to get updated with new software in the market, and to add options to the software for additional services. However, they are not widely involved in the selection of the system. 
Table 7. Liceo service providers' ratings on system selection

\begin{tabular}{|c|c|c|}
\hline System Selection & Weighted Mean & Verbal Description \\
\hline $\begin{array}{l}\text { The ICT system has been adjusted to the existing system of } \\
\text { the university }\end{array}$ & 3.30 & Very Satisfactory \\
\hline $\begin{array}{l}\text { ICT system is flexible to any additional functions for } \\
\text { needed services }\end{array}$ & 3.25 & Very satisfactory \\
\hline ICT involves users intensively in the system selection & 3.16 & Satisfactory \\
\hline Uses of standard software already available in the market & 3.32 & Very Satisfactory \\
\hline Mean & 3.25 & Very Satisfactory \\
\hline
\end{tabular}

Table 8 reveals the Liceo clients' ratings on system selection. Overall, system selection was rated satisfactory (2.69). The following indicators were rated satisfactory: the system can adjust to the existing system of the university (2.76), the system has additional functions for additional services (2.68), the system uses standard software available in the market (2.62), and the system intensity involves users in the system selection (2.66). As revealed, the clients are satisfied with the system selection of ICT especially on the system's capacity to adjust to the needs of the clients.

Table 8. Liceo clients' ratings on system selection

\begin{tabular}{|c|c|c|}
\hline System Selection & Weighted Mean & Verbal Description \\
\hline The system adjusts to the existing system of the university & 2.76 & Satisfactory \\
\hline The system has additional functions for additional services & 2.68 & Satisfactory \\
\hline $\begin{array}{l}\text { The system involves users intensively in the system selection for the } \\
\text { university }\end{array}$ & 2.62 & Satisfactory \\
\hline The system uses standard software available in the market & 2.66 & Satisfactory \\
\hline 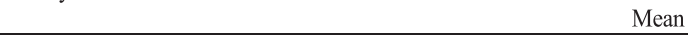 & 2.69 & Satisfactory \\
\hline
\end{tabular}

Table 9 shows the Liceo service providers' ratings on ICT staff's skills/capabilities. Rated the highest (very satisfactory) was the ICT staff's ability to communicate with the end user during the project implementation (3.25). However, rated satisfactory were the following indicators: ICT staff's creation of group to handle the operations and maintenance of the system (3.20), a good relationship with the users (3.11), letting ICT professionals handle the system (3.0), and the provision for a continued training regarding hardware and application software (3.00). Overall, the Liceo service providers rated satisfactory the ICT staff's skills/capabilities. As revealed, the Liceo service providers are moderately satisfied with the staff's skills/capabilities in handling the system. Highest satisfaction shown is with the ICT staff's ability to communicate with the users. This implies that their clients understand their methods of servicing them. The ICT staff's trainings and number of years in service enable them to maintain the system well and effectively relate themselves to the clients.

Table 9. Liceo service providers' ratings on ICT staff's skills/capabilities

\begin{tabular}{|c|c|c|}
\hline ICT Staff Skills/ Capabilities & Weighted Mean & Verbal Description \\
\hline $\begin{array}{l}\text { The staff that handles the system are mainly composed if IT } \\
\text { professionals with experience and capabilities of run the system }\end{array}$ & 3.00 & Satisfactory \\
\hline $\begin{array}{l}\text { ICT Staff communicates with the end users during project } \\
\text { implementation }\end{array}$ & 3.25 & Very Satisfactory \\
\hline $\begin{array}{l}\text { ICT staff has continuous training regarding hardware and application } \\
\text { software }\end{array}$ & 3.00 & Satisfactory \\
\hline $\begin{array}{l}\text { Creates the group to handle the operation and maintenance of the } \\
\text { system }\end{array}$ & 3.20 & Satisfactory \\
\hline ICT Staff has a good relationship with the users. & 3.11 & Sati \\
\hline Mean & 3.11 & Satisfactory \\
\hline
\end{tabular}


Table 10 shows the Liceo clients' ratings on ICT staff's skills/capabilities. The overall mean of 2.69 reveals that the ICT staff's skills/capabilities were perceived satisfactory by the clients. All indicators were likewise rated satisfactory. These included the staff's expertise in handling the system (2.89), staff's ability to handle the operations and the maintenance of the system effectively (2.70), staff's ability to communicate with the end users during the project implementation (2.63), and staff's having good relationships with the users (2.54). The highly rated staff's skill is the ability to handle the systems. They can easily fix any malfunctions, thus ensuring quick normal resumption of the operation. With the lowest rating was the staff's ability to establish good relationship with the clients. They are perceived strict when serving the clients.

Table 10. Distribution of Liceo clients in terms of ICT staff skills/capabilities

\begin{tabular}{|c|c|c|}
\hline ICT Staff Skills/ Capabilities & Weighted Mean & Verbal Description \\
\hline $\begin{array}{l}\text { The staff that handles the system is with experience and capabilities to } \\
\text { run the system. }\end{array}$ & 2.89 & Satisfactory \\
\hline $\begin{array}{l}\text { ICT Staff communicates with the end users during project } \\
\text { implementation. }\end{array}$ & 2.63 & Satisfactory \\
\hline $\begin{array}{l}\text { Staff handles the operation and the maintenance of the system } \\
\text { effectively. }\end{array}$ & 2.70 & Satisfactory \\
\hline ICT Staff has good relationship with the users. & 2.54 & Satisfactory \\
\hline 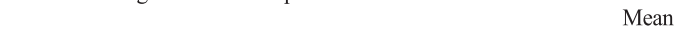 & 2.69 & Satisfactory \\
\hline
\end{tabular}

Table 11 shows the Liceo service providers' perception on the existing ICT practices. Rated very satisfactory were ICT as a tool in using resources more flexibly and economically (3.40) and as a tool for competition advantage and survival (3.40). However, rated satisfactory were the following indicators: ICT as a tool for day to day activity (3.15) and as a tool for communicating users and clients (3.05). Overall, the existing ICT practices were rated very satisfactory (3.26). The findings imply that the service providers have easy access to the system. The existing ICT practices give the school competition advantage, thus the school attracts more customers.

Table 11. Liceo service providers' ratings on existing practices of ICT

\begin{tabular}{|c|c|c|}
\hline Existing Practices & Weighted Mean & Verbal Description \\
\hline ICT as a tool in day-to-day activity & 3.15 & Satisfactory \\
\hline ICT as a tool for communicating users, and clients. & 3.05 & Satisfactory \\
\hline ICT as a tool for competition advantage and survival & 3.40 & Very Satisfactory \\
\hline Make ICT as a tool for using resources more flexibly and economically & 3.40 & Very Satisfactory \\
\hline Mean & 3.26 & Very Satisfactory \\
\hline
\end{tabular}

Table 12 shows the Liceo clients' ratings on the existing ICT practices. All the existing ICT practices were rated satisfactory by the clients. Rated the highest was ICT as a tool for day-to-day activity (2.71), followed by ICT as a tool for using resources more flexibly and economically (2.66), as a tool for communicating users and clients (2.64), and as a tool for competition advantage and survival (2.64). The findings imply that the clients have not maximized the use of ICT as tool for day- 
to-day activity, for communicating other users, and for accessing information.

Table 12. Liceo client's ratings on existing practices of ICT

\begin{tabular}{|c|c|c|}
\hline Existing Practices & Weighted Mean & Verbal Description \\
\hline ICT is a tool for day-to-day activity & 2.71 & Satisfactory \\
\hline ICT as a tool for communicating users, and clients. & 2.64 & Satisfactory \\
\hline Make ICT as a tool for competition advantage and survival & 2.64 & Satisfactory \\
\hline Make ICT as a tool in using resources more flexibly and economically & 2.66 & Satisfactory \\
\hline Mean & 2.80 & Satisfactory \\
\hline
\end{tabular}

Table 13 shows the summary on LDCU service providers' ratings on the extent of ICT practices. Rated very satisfactory were the existing ICT practices (3.26). However, rated satisfactory were the following indicators: system selection (3.25), system restructuring (3.21), and ICT staff skills/capabilities (3.11). Overall, the extents of ICT practices were rated satisfactory. The findings imply that the ICT practices of the service providers have enhanced student services.

\begin{tabular}{|c|c|c|c|}
\hline ICT Practices & & Weighted Mean & $\begin{array}{c}\text { Verbal } \\
\text { Description }\end{array}$ \\
\hline System restructuring & & 3.21 & Satisfactory \\
\hline System selection & & 3.25 & Satisfactory \\
\hline ICT staff's skills/capabilities & & 3.11 & Satisfactory \\
\hline \multirow[t]{2}{*}{ Existing practices of ICT } & & 3.26 & Very Satisfactory \\
\hline & Mean & 3.20 & Satisfactory \\
\hline
\end{tabular}

Table 14 shows the summary of Liceo clients' ratings on the extent of ICT practices. The overall mean of 2.70 reveals that the extents of ICT practices were perceived satisfactory by the clients. All indicators were likewise rated satisfactory. These included the existing ICT practices (2.80), ICT staff's skills/capabilities (2.69), system selection (2.69), and system restructuring (2.62). Rated the highest were the existing ICT practices. This implies that the clients understand the service system used to serve them. On the other hand, rated the lowest is the system restructuring. The clients find themselves less involved in designing the system.

\begin{tabular}{|c|c|c|c|}
\hline ICT Practices & & Weighted Mean & $\begin{array}{c}\text { Verbal } \\
\text { Description }\end{array}$ \\
\hline System restructuring & & 2.62 & Satisfactory \\
\hline System selection & & 2.69 & Satisfactory \\
\hline ICT staff's skills/capabilities & & 2.69 & Satisfactory \\
\hline \multirow[t]{2}{*}{ Existing practices of ICT } & & 2.80 & Satisfactory \\
\hline & Mean & 2.70 & Satisfactory \\
\hline
\end{tabular}

\section{Level of the ICT Applications}

Table 15 shows the Liceo service providers' ratings on ICT applications in terms of functionality. The ICT applications with very satisfactory rating were word processing (3.40), spreadsheets (3.20), and Internet downloads (3.20). 
Presentations (3.00), project management (2.58), visual basic programming (2.47), java programming (2.22), power builder programming (2.22), and c++ programming (2.24) were rated satisfactory. Overall, the ICT applications were rated satisfactory (2.73) by Liceo service providers. Moreover, on information functionality, paper communication (3.40) and information sharing (3.30) were rated very satisfactory while updating and following up transactions and documents (3.00) was rated satisfactory. Word processing was rated the highest for it is used in their daily work. It is used for writing memos and reports and for compiling information. Spreadsheet is also widely used for figures and budget. The Internet is used for accessing and downloading files. Among the indicators of information functionality, paper communication is widely used. Such communication includes memos, letters, reports, and other important manuscripts.

Table 15. Liceo services providers' ratings on ICT application in terms of functionality

\begin{tabular}{|c|c|c|c|}
\hline \multirow{2}{*}{\multicolumn{4}{|c|}{$\begin{array}{l}\text { Functionality } \\
\text { Windows-based Applications }\end{array}$}} \\
\hline & & & \\
\hline Word Processing (e.g. MS Word, Open Office writer) & & 3.40 & Very Satisfactory \\
\hline Spreadsheet (e.g. Excel, Open office Calc) & & 3.20 & Very Satisfactory \\
\hline Presentations (e.g.Powerpoint, Open Office Impress) & & 3.00 & Satisfactory \\
\hline Project Management (e.g. MS Project, Project Planner & & 2.58 & Satisfactory \\
\hline Visual Basic Programming & & 2.47 & Satisfactory \\
\hline Power builder Programming & & 2.22 & Fair \\
\hline Java Programming & & 2.22 & Satisfactory \\
\hline $\mathrm{C}++$ Programming & & 2.24 & Satisfactory \\
\hline Internet(Search, downloads) & & 3.20 & Very Satisfactory \\
\hline & Mean & 2.73 & Satisfactory \\
\hline Information Functionality & & & \\
\hline Updates and follow ups transaction, documents & & 3.00 & Satisfactory \\
\hline Information Sharing & & 3.30 & Very Satisfactory \\
\hline Paper communication (memos, letters and faxes) & & 3.40 & Satisfactory \\
\hline & Mean & 3.11 & Satisfactory \\
\hline
\end{tabular}

Table 16 presents the Liceo clients' ratings on ICT applications in terms of functionality. Overall the functionality of ICT application was satisfactory (2.77). As revealed, all Windows-based applications, such as word processing (3.03), spreadsheet (2.89), Internet (2.88), presentations (2.85), visual basic programming (2.84), project management (2.63), power builder programming (2.66), java programming (2.65), and C++ programming (2.61) were rated satisfactory by the Liceo clients. In terms of information functionality, updating and following up transactions and documents (2.84), information sharing (2.57) and paper communication (2.49) were all rated a satisfactory. As revealed, the clients widely use word processing and Windows-based applications for updating and following up transactions and documents and for processing paper communications. 
Table 16. Liceo clients' ratings on ICT application in terms of functionality

\begin{tabular}{|c|c|c|c|}
\hline Functionality & & Weighted Mean & Verbal Description \\
\hline Windows-based Applications & & & \\
\hline Word Processing (e.g. MS Word, Open Office writer) & & 3.03 & Satisfactory \\
\hline Spreadsheet (e.g. Excel, Open office Calc) & & 2.89 & Satisfactory \\
\hline Presentations (e.g.Powerpoint, Open Office Impress) & & 2.85 & Satisfactory \\
\hline Project Management (e.g. MS Project, Project Planner & & 2.63 & Satisfactory \\
\hline Visual Basic Programming & & 2.84 & Satisfactory \\
\hline Power builder Programming & & 2.66 & Satisfactory \\
\hline Java Programming & & 2.65 & Satisfactory \\
\hline $\mathrm{C}++$ Programming & & 2.61 & Satisfactory \\
\hline \multirow{2}{*}{ Internet(Search, downloads) } & & 2.88 & Satisfactory \\
\hline & Mean & 2.77 & Satisfactory \\
\hline \multicolumn{4}{|l|}{ Information Functionality } \\
\hline Updates and follow ups transaction, and documents & & 2.84 & Satisfactory \\
\hline Information Sharing & & 2.57 & Satisfactory \\
\hline Paper communication (memos, letters and faxes) & & 2.49 & Satisfactory \\
\hline & Mean & 2.77 & Satisfactory \\
\hline
\end{tabular}

Table 17 shows the Liceo service providers' ratings on ICT applications in terms of availability. The availability of Windows-based applications, the availability of assistance in the event problems will occur (3.30), and the quality of data provided (3.30) were rated very satisfactory. However, the availability of data across business functions (3.16) and of workstation per user (3.15) was rated satisfactory. Overall, the service providers of Liceo rated satisfactory the availability of ICT applications...

In terms of information performance, workstation per user (3.20), availability of database and network (3.20), speed of sending and receiving information (3.20), quality of data provided (3.10), and availability across business functions (3.05) were all rated satisfactory.

The findings imply that the service providers of LDCU are highly satisfied with the quality of data being provided to their clients since the clients are always updated on matters concerning the school institution via the Internet. Also, they are highly satisfied with the availability of assistance desk since a standby unit is in place to assist whenever a problem takes place.

Table 17. Liceo service providers' ratings on ICT applications in terms of availability

\begin{tabular}{|c|c|c|}
\hline Availability & Weighted Mean & Verbal Description \\
\hline Windows-based applications & & \\
\hline Quality of data provided & 3.30 & Very Satisfactory \\
\hline Availability of assistance desk in the event problems will come out. & 3.30 & Very Satisfactory \\
\hline Workstation per user & 3.15 & Satisfactory \\
\hline Availability of data across business functions & 3.16 & Satisfactory \\
\hline Mean & 3.22 & Very Satisfactory \\
\hline Information performance & & \\
\hline Quality of data/reports provided & 3.10 & Satisfactory \\
\hline Availability of database and network & 3.20 & Satisfactory \\
\hline Workstation per user & 3.20 & Satisfactory \\
\hline Speed of sending and receiving information & 3.20 & Satisfactory \\
\hline Availability across business functions & 3.05 & Satisfactory \\
\hline Mean & 3.15 & Satisfactory \\
\hline
\end{tabular}

Table 18 shows the Liceo clients' ratings on ICT applications in terms of availability. Overall, the availability of all Windows-based applications was satisfactory as reflected by the overall mean of 2.59 . The availability of assistance 
desk (2.69), workstation per user (2.63), quality of data provided (2.54), and availability of data across business functions (2.49) were rated satisfactory. In terms of information performance, availability of database and network (2.73), workstation per user (2.64), quality of data/reports provided (2.58), speed of sending and receiving information (2.56), and availability of across business functions (2.50) were rated satisfactory. The clients' low satisfaction level implies that the service providers do not respond immediately to the clients' concerns and needs, the workstations cannot accommodate all users, and the data needed cannot be accessed fast.

Table 18. Liceo clients' ratings on ICT application in terms of availability

\begin{tabular}{|c|c|c|}
\hline Availability & Weighted Mean & Verbal Description \\
\hline Windows-based applications & & \\
\hline Quality of data provided & 2.54 & Satisfactory \\
\hline Availability of assistance desk in the event problems will come out & 2.69 & Satisfactory \\
\hline Workstation per user & 2.63 & Satisfactory \\
\hline Availability of data across business functions & 2.49 & Satisfactory \\
\hline (5) & 2.59 & Satisfactory \\
\hline Information performance & & \\
\hline Quality of data/reports provided & 2.58 & Satisfactory \\
\hline Availability of database and network & 2.73 & Satisfactory \\
\hline Workstation per user & 2.64 & Satisfactory \\
\hline Speed of sending and receiving information & 2.56 & Satisfactory \\
\hline Availability across business functions & 2.50 & Satisfactory \\
\hline Mean & 2.60 & Satisfactory \\
\hline
\end{tabular}

Table 19 presents the Liceo service providers' ratings on ICT applications in terms of maintainability. Overall, the maintainability of the ICT applications was rated satisfactory (3.10). Among the indicators, expandability of the system (3.25) and service maintenance (3.25) were rated very satisfactory while spares backup (hardware and software) and level of knowledge of personnel handling the system (2.95) were rated satisfactory. The findings suggest that the service providers of Liceo are able to maintain a high efficient system because of the availability of spares backup and the personnel's knowledge on handling the system.

Table 19. Liceo service providers' ratings on ICT applications in terms of maintainability

\begin{tabular}{|c|c|c|c|}
\hline Maintainability & & Weighted Mean & Verbal Description \\
\hline Knowledge of personnel handling the system & & 2.95 & Satisfactory \\
\hline Spares backup (hardware and software) & & 2.95 & Satisfactory \\
\hline Service Maintenance & & 3.25 & Very Satisfactory \\
\hline Expandability of the system & & 3.25 & Very Satisfactory \\
\hline & Mean & 3.10 & Satisfactory \\
\hline
\end{tabular}

Table 20 shows the Liceo clients' ratings on ICT applications in terms of maintainability of the system. Overall, the level of maintainability of ICT applications was rated satisfactory (2.60). As revealed, the uses of the current system (2.65), the observance of standards of customer care and institutional policies and regulations (2.55), and the knowledge of the personnel on handling the system (2.50) were rated satisfactory by the Liceo clients. As perceived by the clients, the 
system is satisfactorily maintained, the uses of the current system are satisfactorily tapped, the standards of customer care and institutional policies and regulations are satisfactorily observed, and the system is satisfactorily maintained.

Table 20. Liceo clients' ratings on ICT application in terms of maintainability

\begin{tabular}{lcl}
\multicolumn{1}{c}{ Maintainability } & Weighted Mean & $\begin{array}{c}\text { Verbal } \\
\text { Description }\end{array}$ \\
\hline Personnel handling the system are knowledgeable. & 2.50 & $\begin{array}{c}\text { Satisfactory } \\
\text { The system is well maintained }\end{array}$ \\
The uses of the current system are expanded. & 2.71 & Satisfactory \\
Knows and applies the standards of customer care and institutional & 2.65 & Satisfactory \\
policies and regulations are observed. & 2.55 & \\
& & Satisfactory \\
\end{tabular}

Table 21 presents the Liceo service providers' ratings on ICT applications in terms of utilization. As to the level of knowledge on applications, the overall rating was satisfactory (2.67). Rated very satisfactory was the spreadsheet (3.40), while rated satisfactory were presentations (3.15), word processing and project management (2.95), visual basic programming (2.58), Internet (2.42), power builder programming (2.37), java programming (2.28), and C++ programming (2.26). As to the system's functions, all the indicators were rated satisfactory. Rated the highest among the indicators was the spreadsheet (3.11), while power builder programming and java programming (2.32) were rated the lowest. Moreover, the evaluation of trained staff that use Windows-based applications (3.16) and the speed of providing data (2.67) were rated satisfactory.

The service providers' knowledge on the ICT applications is acquired through trainings and seminars they attended. Their knowledge has equipped them for the use of the system. The functions commonly used are spreadsheet for financial reports, figures, charts, and tables; presentations for presenting the required output of the department; word processing for letters, faxes, and other communications; project management for planning, and implementing; visual basic programming for the basic programming language of the system; and the Internet for downloading and searching files in the web. Power builder programming, java programming, and $\mathrm{C}++$ programming are available in the system but are seldom being used.

Table 21. Liceo service providers' ratings on ICT application in terms of utilization

\begin{tabular}{|c|c|c|}
\hline Utilization & Weighted Mean & Verbal Description \\
\hline \multicolumn{3}{|l|}{ Level of Knowledge on Applications } \\
\hline Word Processing (e.g. MS Word, Open Office writer) & 2.95 & Satisfactory \\
\hline Spreadsheet (e.g. Excel, Open office Calc) & 3.40 & Very Satisfactory \\
\hline Project Management (e.g. MS Project, Project Planner & 2.95 & Satisfactory \\
\hline Visual Basic Programming & 2.58 & Satisfactory \\
\hline Power builder Programming & 2.37 & Satisfactory \\
\hline $\mathrm{C}++$ Programming & 2.26 & Satisfactory \\
\hline \multirow[t]{2}{*}{ Internet(Search, downloads) } & 2.42 & Satisfactory \\
\hline & 2.67 & Satisfactory \\
\hline \multicolumn{3}{|l|}{ Functionality (Functions of the System) } \\
\hline Word Processing (e.g. MS Word, Open Office writer) & 3.05 & Satisfactory \\
\hline Spreadsheet (e.g. Excel, Open office Calc) & 3.11 & Satisfactory \\
\hline
\end{tabular}


(Table 21. Continued)

\begin{tabular}{|c|c|c|}
\hline Utilization & Weighted Mean & Verbal Description \\
\hline Presentations (e.g. PowerPoint, Open Office Impress) & 3.05 & Satisfactory \\
\hline Project Management (e.g. MS Project, Project Planner & 2.80 & Satisfactory \\
\hline Visual Basic Programming & 2.63 & Satisfactory \\
\hline Power builder Programming & 2.32 & Fair \\
\hline Java Programming & 2.32 & Fair \\
\hline $\mathrm{C}++$ Programming & 2.53 & Satisfactory \\
\hline Internet(Search, downloads) & 2.59 & Satisfactory \\
\hline Mean & 2.59 & Satisfactory \\
\hline Evaluation of trained staff who use Windows-based applications & 3.16 & Satisfactory \\
\hline Speedy provision of data & 2.67 & Satisfactory \\
\hline Mean & 2.56 & Satisfactory \\
\hline
\end{tabular}

Table 22. Liceo clients' ratings on ICT application in terms of utilization

\begin{tabular}{|c|c|c|c|}
\hline Utilization & & Weighted Mean & Verbal Description \\
\hline \multicolumn{4}{|l|}{ Level of Knowledge Applications } \\
\hline Word Processing (e.g. MS Word, Open Office writer) & & 2.52 & Satisfactory \\
\hline Spreadsheet (e.g. Excel, Open office Calc) & & 2.87 & Satisfactory \\
\hline Presentations (e.g.Powerpoint, Open Office Impress) & & 2.83 & Satisfactory \\
\hline Project Management (e.g. MS Project, Project Planner & & 2.72 & Satisfactory \\
\hline Visual Basic Programming & & 2.68 & Satisfactory \\
\hline Power builder Programming & & 2.66 & Satisfactory \\
\hline Java Programming & & 2.60 & Satisfactory \\
\hline $\mathrm{C}++$ Programming & & 2.54 & Satisfactory \\
\hline Internet(Search, downloads) & & 2.56 & Satisfactory \\
\hline & Mean & 2.65 & Satisfactory \\
\hline \multicolumn{4}{|l|}{ Functionality (Functions of the System) } \\
\hline Word Processing (e.g. MS Word, Open Office writer) & & 2.81 & Satisfactory \\
\hline Spreadsheet (e.g. Excel, Open office Calc) & & 2.85 & Satisfactory \\
\hline Presentations (e.g. PowerPoint, Open Office Impress) & & 2.78 & Satisfactory \\
\hline Project Management (e.g. MS Project, Project Planner & & 2.69 & Satisfactory \\
\hline Visual Basic Programming & & 2.75 & Satisfactory \\
\hline Power builder Programming & & 2.65 & Satisfactory \\
\hline Java Programming & & 2.55 & Satisfactory \\
\hline $\mathrm{C}++$ Programming & & 2.53 & Satisfactory \\
\hline \multirow[t]{2}{*}{ Internet(Search, downloads) } & & 2.42 & Satisfactory \\
\hline & Mean & 2.93 & Satisfactory \\
\hline Evaluation of trained staff that use Windows -based applications & & 2.48 & Satisfactory \\
\hline \multirow[t]{2}{*}{ Speed provision of data } & & 2.69 & \\
\hline & Mean & 2.59 & Satisfactory \\
\hline
\end{tabular}

Table 22 presents the Liceo clients' ratings on ICT applications in terms of utilization. As to the knowledge on the applications, all ICT applications were known satisfactorily as revealed by the overall rating of 2.65. All indicators of utilization were rated satisfactory. There were spreadsheet, 2.65; presentations, 2.83; project management, 2.72; visual basic programming, 2.68; power builder programming, 2.66; word processing, 2.52; java programming, 2.60; Internet, 2.56; and C++ programming, 2.54. In terms of the functions of the system, all the applications were rated satisfactory (2.93). Rated the highest was the spreadsheet (2.85), while the Internet was rated the lowest. On the other hand, the evaluation of trained staff that use Windows-based applications (2.48) and the speed in providing data (2.69) were rated satisfactory. As found out, the service providers were trained in the proper use of the system and the proper way of serving the clients. The staffs that use Windows-based applications were evaluated satisfactorily for they were able to meet the clients' needs. 
The Liceo service providers' ratings on ICT applications in terms of performance level is presented in Table 3. As revealed, administrative and operational process (3.35), maintenance of operation process (3.35), ICT creating and altering employees' know-how to get things done in the existing system (3.32), and better production process (3.26) were all rated very satisfactory. However, generating and submitting timely report to the management for decision-making (3.05) was rated satisfactory. Overall, the performance level of ICT applications was rated very satisfactory. As cited by the service providers, performance level is high because the service policies and procedures are properly implemented.

Table 23. Liceo service providers' ratings on ICT applications in terms of performance level

\begin{tabular}{|c|c|c|}
\hline Performance Level & Weighted Mean & Verbal Description \\
\hline Administrative and operational process & 3.35 & Very Satisfactory \\
\hline Maintenance and operation process & 3.35 & Very Satisfactory \\
\hline $\begin{array}{l}\text { Creating and altering employees to get things done in the existing } \\
\text { system }\end{array}$ & 3.32 & Very Satisfactory \\
\hline Availability of data across business functions & 3.26 & Very Satisfactory \\
\hline Better production process & 3.26 & Very Satisfactory \\
\hline \multirow{2}{*}{$\begin{array}{l}\text { Generating and submitting timely report to the management for } \\
\text { decision making } \\
\text { Mean }\end{array}$} & 3.05 & Satisfactory \\
\hline & 3.27 & Very Satisfactory \\
\hline
\end{tabular}

Table 24 shows the Liceo clients' ratings on the performance level of ICT. Overall, the ICT's performance level was satisfactory (2.75). "Maintenance of ICT makes the school more efficient" (2.90), "ICT creates and alters school administrations' know-how to get things done in the existing system" (2.85), "ICT improves the operation of the school" (2.76), "data across business functions are available" (2.75), "Research and processing of students' complaints are undertaken" (2.72), "Timely information is provided to other staff with student support roles" (2.70), "School policy on student exception is implemented" (2.69), and "Cases under consideration are prepared and processed" (2.64) were indicators rated satisfactory by the clients. The findings reveal that the Liceo clients are moderately satisfied with the service providers' level of performance in the use of ICT.

Table 24. Liceo clients' ratings on ICT applications in terms of performance level

\begin{tabular}{|c|c|c|}
\hline Performance Level & Weighted Mean & Verbal Description \\
\hline ICT improves the operation of the school & 2.76 & Satisfactory \\
\hline Maintenance of ICT makes the school more efficient & 2.90 & Satisfactory \\
\hline $\begin{array}{l}\text { ICT creates and alters school administration's on know-how to get } \\
\text { things done in the existing system }\end{array}$ & 2.85 & Satisfactory \\
\hline Availability of data across business functions & 2.75 & Satisfactory \\
\hline $\begin{array}{l}\text { Implement the school policy on student exceptions such as fee } \\
\text { waiver }\end{array}$ & 2.69 & Satisfactory \\
\hline Prepare and process cases under consideration. & 2.64 & Satisfactory \\
\hline Undertake research and processing of student complaint cases & 2.72 & Satisfactory \\
\hline Provide timely information to other staff with student support roles & 2.70 & Satisfactory \\
\hline Mean & 2.75 & Satisfactory \\
\hline
\end{tabular}

Table 25 shows the summary of Liceo service providers' ratings on the ICT applications. Overall, the ICT applications were rated satisfactory (3.01). Among these indicators, performance level (3.27) was rated very satisfactory, while availability (3.18), maintainability (3.10), functionality (2.92), and utilization (2.60) were rated satisfactory. The findings suggest that the service providers of Liceo are highly efficient in doing their tasks and handling the system. 
Table 25. Summary on Liceo service providers' ratings on the ICT applications

Functionality

Availability

Maintainability

Utilization

Performance level

$$
\text { ICT Applications }
$$

$\begin{array}{rr} & \text { Weighted } \\ & 2.92 \\ 3.18 \\ 3.10 \\ 2.60 \\ 3.27 \\ \text { Mean } \quad 3.01\end{array}$

Verbal Description

Satisfactory

Satisfactory

Satisfactory

Satisfactory

Very Satisfactory Satisfactory

Table 26 shows the summary of Liceo clients' ratings on the ICT applications. Overall, the ICT applications were rated satisfactory (2.68). As revealed, functionality (2.77), performance level (2.75), utilization (2.72), maintainability (2.60), and availability (2.59) were rated satisfactory by the clients.

Table 26. Summary of Liceo clients' ratings on the ICT applications

\begin{tabular}{lccc}
\hline & ICT Applications & Weighted Mean & Verbal Description \\
\hline Functionality & 2.77 & Satisfactory \\
Availability & 2.59 & Satisfactory \\
Maintainability & 2.60 & Satisfactory \\
Utilization & & 2.72 & Satisfactory \\
Performance level & Mean & 2.75 & Satisfactory \\
& & 2.68 & Satisfactory \\
\hline
\end{tabular}

Table 27 presents the results of the t-test on the ratings of the Liceo service providers and clients on ICT adoption in terms of the existing practices. The calculated $t$-value of 0.53 was lower than the critical $t$ value of 2.015 ; therefore, there was no significant difference in the ratings of the service providers and the clients on ICT adoption in terms of the existing practices. The clients had higher satisfaction level on the existing practices than the employees. Such is so since the students are happy to see ICT being used while employees may want a better kind of ICT being used.

Table 27. Results of T-Test on the ratings of service providers and clients on ICT Adoption in terms of existing practices

\begin{tabular}{lccc}
\hline & Clients & \multicolumn{2}{c}{ Service providers } \\
Average (mean) & Qualitative Description & Average (mean) & qualitative Description \\
\hline 2.58 & Satisfactory & 2.37 & Fair \\
T Calculated value $=0.53$ & T Critical (table) value $=2.015$ & $\mathrm{df}=5$ & Prob. $=.616$ \\
$\begin{array}{l}\text { Conclusion: T calculated value is } \\
\text { Interpretation : Not Significant }\end{array}$ & $\begin{array}{l}\text { T critical (table) value } \\
\text { Decision on Ho: Not Rejected }\end{array}$ & & \\
\hline
\end{tabular}

Table 28 shows the results of the t-test on the ratings of the Liceo service providers and clients on the ICT adoption in terms of performance level. The calculated $t$-value of 3.12 was higher than the $t$ critical value of 1.671 ; herefore, there was a significant difference in the ratings of the clients and providers. The higher ratings on ICT perform by clients indicate a satisfaction on the efficiency of service to match the needs of clients.

Table 28. Result of T-test on the ratings of service providers and clients on ICT adoption in terms of performance

\begin{tabular}{|c|c|c|c|c|}
\hline \multicolumn{2}{|c|}{ Clients } & \multicolumn{3}{|c|}{ Service Providers } \\
\hline Average (mean) & Qualitative Description & Average (mean) & & Qualitative Description \\
\hline 2.90 & Satisfactory & 2.55 & & Satisfactory \\
\hline $\mathrm{T}$ Calculated value $=3.12$ & $\mathrm{~T}$ Critical (table) value $=1.671$ & $\mathrm{df}=53$ & $=.003$ & \\
\hline \multicolumn{5}{|c|}{ Conclusion: $\mathrm{T}$ calculated value is $>\mathrm{T}$ critical (table) value } \\
\hline Interpretation : Significan & Decision on Ho: Rejected & & & \\
\hline
\end{tabular}




\section{Level of Efficiency of the Student Services}

Table 29 shows the efficiency ratings for the Registrar's Office. As revealed, updating followed-up transactions and documents, knowledge on operating the system, and processing of enrollment were rated very satisfactory. However, the processing of Transcript of Records (TOR), diploma, and honorable dismissal was rated satisfactory (3.21). Overall, the rating on the efficiency of the student services of the Registrar's Office was satisfactory. The Registrar's Office effectively updates followed-up documents and transactions needed by the clients and processes the enrollment fast. The enrollment would take just half of the day. However, the release of records, diploma, and honorable dismissal would take a few days.

Table 29. Liceo service providers' ratings on the efficiency of students services of the registrar's office

\begin{tabular}{|c|c|c|}
\hline Registrar's Office & Weighted Mean & Verbal Description \\
\hline $\begin{array}{l}\text { Fast processing of transcript of records (TOR), diploma and } \\
\text { honorable dismissal }\end{array}$ & 3.21 & Satisfactory \\
\hline Updates and following up of transactions, documents & 3.26 & Very Satisfactory \\
\hline Knowledge in operating the system & 3.26 & Very Satisfactory \\
\hline Processing of enrollment & 3.26 & Very Satisfactory \\
\hline Mean & 3.24 & Satisfactory \\
\hline
\end{tabular}

Table 30 presents the Liceo clients' ratings on the efficiency of the student services of the Registrar's Office. Overall, the efficiency rating for the Registrar's student services was satisfactory (2.45). As rated by the Liceo clients, the processing of enrollment (2.60), processing of Transcript of Records (TOR) and diploma and honorable dismissal (2.56), and knowledge on operating the system (2.35) were satisfactory. However, updating transactions and followed-up documents (2.31) was rated fair. The clients know for a fact that enrollment can be completed for just half of the day and that records, diploma, and honorable dismissal can be obtained within few days. However, the fair rating for the knowledge on operating the system indicates that there are times when errors are committed in the processing of their documents.

Table 30. Liceo clients' ratings on the efficiency of student services of the registrar's office

\begin{tabular}{|c|c|c|}
\hline Registrar's Office & Weighted Mean & Verbal Description \\
\hline $\begin{array}{l}\text { Processing of transcript of records (TOR), diploma and honorable } \\
\text { dismissal }\end{array}$ & 2.56 & Satisfactory \\
\hline Updating and following up of transactions, documents & 2.31 & Fair \\
\hline Knowledge in operating the system & 2.35 & Satisfactory \\
\hline Processing of enrollment & 2.60 & Satisfactory \\
\hline Mean & 2.45 & Satisfactory \\
\hline
\end{tabular}

Table 31 reveals that the overall efficiency rating for the student services of the Cashier's Office was satisfactory (3.21). Rated the highest (very satisfactory) was the updating of followed-up transactions or documents (3.26). Knowledge on operating the system (3.21) and processing of payments (3.16) were rated 
satisfactory. The findings imply that the Cashier's Office performs its tasks to the satisfaction of the clients. Clients' accounts are updated before the payments are processed fast. As observed by the clients, it would take seconds to pay their fees.

Table 31. Liceo service providers' rating on the efficiency of students' services of the cashier's office

\begin{tabular}{|c|c|c|c|}
\hline Cashier & & Weighted Mean & Verbal Description \\
\hline Fast processing of payments & & 3.16 & Satisfactory \\
\hline Updates and follow-ups of transactions, documents & & 3.26 & Very Satisfactory \\
\hline Level of knowledge in operating the system & & 3.21 & Satisfactory \\
\hline & Mean & 3.21 & Satisfactory \\
\hline
\end{tabular}

Table 32 reveals that the clients' overall efficiency rating for the student services of the Cashier's Office was fair (2.30). Updating followed-up transactions or documents (2.69), knowledge on operating the system (2.66), processing of payments (2.62), and fast processing of refunds (2.60) were poorly rated. The findings imply that the LDCU clients are not satisfied with the student services of the Cashier's Office. As observed by the clients, the updating of their accounts is delayed, the processing of their fees is erroneous, and the processing of their payments and refund is slow.

Table 32. Liceo clients' ratings on the efficiency of student services of the cashier's office

\begin{tabular}{|c|c|c|}
\hline Cashier & Weighted Mean & Verbal Description \\
\hline Fast processing of payments & 2.30 & Fair \\
\hline Updates and follow-ups of transactions, documents & 2.34 & Fair \\
\hline Level of knowledge in operating the system & 2.30 & Fair \\
\hline Fast processing of payments & 2.29 & Fair \\
\hline & 2.30 & Fair \\
\hline
\end{tabular}

Table 33 reveals that the Liceo service providers' overall efficiency rating for the Library's student services was satisfactory (3.21). The only indicator rated very satisfactory was updating followed-up transactions or documents (3.26). Quality of data provided (3.21) and knowledge on operating the system (3.16) was rated satisfactory. As reported by the service providers of Liceo, the library efficiently updates followed-up transactions or documents to facilitate early release of available books in the market. Library materials provided are of latest edition. The Library staff is moderately confident in operating the system.

Table 33. Liceo service providers' rating on the efficiency of student services of the library

\begin{tabular}{|c|c|c|}
\hline Library & Weighted Mean & Verbal Description \\
\hline Quality of data provided (e.g. electronic documents, periodicals) & 3.21 & Satisfactory \\
\hline Updating followed-up transactions or documents & 3.26 & Very Satisfactory \\
\hline Knowledge in operating the system & 3.16 & Satisfactory \\
\hline Mean & 3.21 & Satisfactory \\
\hline
\end{tabular}

Table 34 reveals that the Liceo's clients' overall efficiency rating for the library's student services was fair (2.39). Quality of data provided (3.15) and updating followed-up transactions or documents were rated satisfactory. However, knowledge on operating the system (2.46) was rated fair. The findings imply that the Liceo client's are not satisfied with the student services of the library. As 
reported by the clients, it taken time before a requested book is handed to them and there are only few providers who are highly able to operate the system.

Table 34. Liceo clients' ratings on the efficiency of student services of the library

\begin{tabular}{|c|c|c|}
\hline Library & Weighted Mean & Verbal Description \\
\hline Quality of data provided (e.g. electronic documents, periodicals) & 3.15 & Satisfactory \\
\hline Updating followed-up transactions or documents & 2.55 & Satisfactory \\
\hline Knowledge in operating the system & 2.46 & Fair \\
\hline Mean & 2.39 & Fair \\
\hline
\end{tabular}

Table 35 reveals that the Licean service providers' overall efficiency rating for the Internet Services was satisfactory (3.14). The indicator rated very satisfactory was the processing of data from the web (3.26). The indicators rated satisfactory were monitoring the performance of the school through questionnaires (3.21), updating followed-up transactions and documents (3.11), advertising school programs (3.11), and knowledge on operating the system (3.00). As cited by the service providers, the processing of data from the web is done using advanced hardware and software. Monitoring the performance of the school through questionnaires has a big impact on the current status of the institution. Updating transactions or documents is made fast using the system. Advertising school programs has attracted students to enroll in the university.

Table 35. Liceo service providers' ratings on the efficiency of students services of the internet services

\begin{tabular}{|c|c|c|}
\hline Internet Services & Weighted Mean & Verbal Description \\
\hline Processing of data from the web & 3.26 & Very Satisfactory \\
\hline Updating followed-up transactions and documents & 3.11 & Satisfactory \\
\hline Knowledge in operating the system & 3.00 & Satisfactory \\
\hline Advertising the school programs & 3.11 & Satisfactory \\
\hline Monitoring the performance of the school through questionnaires & 3.21 & Satisfactory \\
\hline Mean & 3.14 & Satisfactory \\
\hline
\end{tabular}

Table 36 reveals that the Liceo clients' overall efficiency rating for the Internet Services was satisfactory (2.51). Monitoring the performance of the school through questionnaires (2.60), advertising school programs (2.56), processing of data from the web (2.51), and updating followed-up transactions or documents (2.50) were rated satisfactory. However, knowledge on operating the system (2.36) was rated fair.

As reported by the clients, the Internet Services enables them to know the school better. The processing of data from the web is made fast using a highly upgraded hardware and software. Also made fast is the updating of transactions or documents through the dial-up system. However, the clients reported that only the student assistant does the supervision, not the provider.

Table 36. Liceo clients' ratings on the efficiency of student services of the internet services

\begin{tabular}{|c|c|c|}
\hline Internet Services & Weighted Mean & Verbal Description \\
\hline Processing of data from the web & 2.51 & Satisfactory \\
\hline Updating followed-up transactions and documents & 2.50 & Satisfactory \\
\hline Knowledge in operating the system & 2.36 & Fair \\
\hline Advertising the school programs & 2.56 & Satisfactory \\
\hline Monitoring the performance of the school through questionnaires & 2.60 & Satisfactory \\
\hline Mean & 2.51 & Satisfactory \\
\hline
\end{tabular}




\section{Comparison of Ratings of the Service Providers and the Clients on the Efficiency of Student Services of the Different Departments}

Table 37 shows the t-test results on the ratings of the clients and service providers on the efficiency of student services of the different departments. The calculated $t$ value of 3.23 was greater than the $t$ critical value of 1.671 ; thus, there was a significant difference in the clients' and providers' ratings on the efficiency of student services of the different departments. A comparison of means indicates that the clients had a higher efficiency rating for students' services than the service providers had.

Table 37. T-test results on the ratings of clients and services providers on the efficiency of student services

\begin{tabular}{cccc}
\hline & CLIENTS & \multicolumn{2}{c}{ SERVICE PROVIDERS } \\
Average (mean) & Qualitative Description & Average (mean) & Qualitative Description \\
\hline 2.60 & Satisfactory & 2.20 & Fair \\
T Calculated value $=3.23$ & T Critical (table) value $=1.671$ & $\mathrm{df}=45$ & Prob. $=.002$ \\
Conclusion: T calculated value is $>$ T critical (table) value & & \\
Interpretation : Not Significant & Decision on Ho: Not Rejected & & \\
\hline
\end{tabular}

\section{Predictors of the efficiency of student services}

Table 38 presents the results of multiple regression on the ratings of the service providers and clients on the existing practices of ICT, ICT implementation performance, and efficiency of student services. As shown by the data, only four variables predicted the efficiency of student services. These predictors included ICT's timely provision of information to other staff with student support roles, ICT as a tool for competition advantage and survival, ICT's capacity to create and alter school administrators' know-how to get things done in the existing system, and ICT as a tool for day-to-day activity. Any increase of these existing practices and performance level of ICT implementation means higher efficiency of student services.

Table 38. Results of multiple regression analysis on the ratings for existing practices of ICT, ICT implementation

\begin{tabular}{lccccccc}
\multicolumn{7}{c}{ performance and efficiency } & of students services \\
\multicolumn{1}{c}{ Variables } & $\begin{array}{c}\text { Regression } \\
\text { Coefficients }\end{array}$ & $\mathrm{R}^{2}$ & $\begin{array}{c}\text { Beta } \\
\text { Coefficient }\end{array}$ & $\begin{array}{c}\mathrm{F} \\
\text { Value }\end{array}$ & $\begin{array}{c}\text { Prob. } \\
\text { Interpretation }\end{array}$ & $\begin{array}{c}\text { Decision } \\
\text { on Ho: }\end{array}$ \\
\hline $\begin{array}{l}\text { Timely Provision of } \\
\text { information to other staff } \\
\text { with student support roles }\end{array}$ & .722500 & .76726 & .360696 & 22.306 & .0000 & Significant & Reject \\
$\begin{array}{l}\text { ICT as a tool for competitive } \\
\text { advantage and survival }\end{array}$ & .695827 & .79341 & .364771 & 26.857 & .0000 & Significant & Reject \\
$\begin{array}{l}\text { ICT creates and alters } \\
\text { administrators know-how to } \\
\text { get things done in the existing }\end{array}$ & & & & & & & \\
$\begin{array}{l}\text { system } \\
\begin{array}{l}\text { ICT as a tool in your day-to- } \\
\text { day activity. }\end{array}\end{array}$ & .640488 & .814065 & .231654 & 10.823 & .0018 & Significant & Reject \\
\hline
\end{tabular}


The respondents' socio-demographic variables did not have any interaction effect on the relationship between the independent variables and efficiency of student services. The service providers and the clients are focused on the efficiency of student services.

\section{CONCLUSIONS}

The ICT practices have satisfactorily met the clients' needs, indicating that the clients have little awareness of the service delivery mechanisms. The service staffs have the basic skills, but have not acquired advanced trainings to hoist services to an excellent level.

The practices and applications of ICT predict the efficiency of student services.

The personal characteristics of the service providers have no bearing on the relationship between the practical applications of ICT and the efficiency of student services.

\section{LITERATURE CITED}

Bas, A.M. (2003). "System performance and clients' satisfaction of the registrar's offices of MSU system: A basis for a service delivery improvement program", Dissertation (DM), Liceo de Cagayan University.

Cummings, M. (2005). "Management information systems for the information age." New York: Mc-Graw Hill Companies Inc.

Cook, D. and Finlayson, H. (1999). "ICT and classroom teaching" USA: Cromwell Press, Trowbordel.

Giarola, B.K. (2004) "Information and communications technology for development, a source book for parliamentarians." New Delhi: Elsevier Publishing Inc.

Lango, A.M. (2005). “IT and organizational learning." New York: Routledge.

Lucas, H. C. Jr. (1997). "Information technology for management”, New York: McGraw-Hill Companies, Inc.

Kallick, B. \& Wilcon, J. M. (2001) “Information technology for schools" USA: A Wiley Company.,

Pearlson, K. E. \& Saunders, C.S. (2005) "Managing and using information systems, a strategic approach."2nd edition. USA: John Wiley and Sons Inc.

Tiin, A. R. Jr. (2002)"Effects of information technology to corporate performance of National Power Corporation Mindanao: basis for corporate productivity", Dissertation (DM), Liceo de Cagayan University.

Zulueta, F. M. \& Costales N. E., Jr. (2004). “Methods of research thesis-writing and applied statistics". Mandaluyong: National Bookstore. 